\title{
Sustainable Seafood Resources by Applying Industry 4.0: A Short Note
}

\author{
Chee Kong Yap ${ }^{1 *}$, Chee Seng Leow ${ }^{2}$, Shih Hao Tony Peng ${ }^{3}$, Chee Wah Yap ${ }^{4}$ and Wai Kong Ng $^{5}$ \\ ${ }^{1}$ Department of Biology, Faculty of Science, Universiti Putra Malaysia, Selangor, Malaysia \\ ${ }^{2}$ Humanology Sdn Bhd, 73-3 Amber Business Plaza, Malaysia \\ ${ }^{3}$ All Cosmos Biotech Holding Corporation, Johor, Malaysia \\ ${ }^{4}$ MES SOLUTIONS, Bandar Kinrara, Selangor, Malaysia \\ ${ }^{5}$ Softwin Technology, Selangor, Malaysia
}

*Corresponding author: Chee Kong Yap, Department of Biology, Faculty of Science, Universiti Putra Malaysia, Selangor, Malaysia.

Received Date: December 02, 2019

Published Date: December 20, 2019

\section{Short Communication}

The First, Second, Third Industrial Revolutions started with the advent of steam and waterpower, electric power and mass manufacturing techniques, and information technology and automation, respectively [1,2]. The Fourth Industrial Revolution, known as Industry 4.0, is a much-discussed topic in the literature nowadays [1]. According to Industrial Internet Consortium (2017) [3], Industry 4.0 is defined as "the integration of complex physical machinery and devices with networked sensors and software, used to predict, control and plan for better business and societal outcomes". When it is looked as a single interpretation of the above, it is rather difficult to connect how the application of the concept Industry 4.0 can help sustain the seafood natural resources from the coastal environment. Generation of economy with seafood products with high quality will certainly make a country to sustain its GDP per capital at the carrying capacity limit or can potentially exceeding it. The idea of this paper is grounded based on logical understanding between seafood sources and industry 4.0.

Managing sustainable coastal natural resources needs integration of three main elements namely economy, social and environmental perspectives. In the Goal \#12 under United Nation's Sustainable Development Goals (UNSDGs), the three keywords 'Economy, Environmental and Social' are mentioned [2]. This clearly shows the interconnection of the three components for sustainable development of a nation. Based on the papers [4] reviewed in this article, although there is no mention of 'Food', the food as a major source is actually under the keyword 'Environmental'. Under UNSDGs, 'increases in living standard for all people' in the Goal \#9 and 'a better quality of life for all' in the Goal \#12, have an ecological interpretation of the important of food safety and security in sustaining both mentioned goals. Hence, the public could be misled when the Food is not seen under Goal \#9 and Goal \#12 under UNSDGs.

Industry is needed and essential for a nation for infrastructure development. The manufacturing industry is much needed to create novel invention and innovation of food packages in addition to nutritional values of the seafood such as the edible soft tissues of marine mussels that contain high level of protein and vitamins $[5,6]$. For example, the use of fish skins has been patented as a novel invention as a source of collagen for cosmetic purpose [7]. Later, may such related or modified methods of extraction or using other species of marine fished have been successfully patented and commercialized. This has positively created space and opportunities for fish market expansion in response to the collagen demand from the consumers. The data from the needs and demand from the public is highly subjective and become meaningless until there is high demand from the public. The fish suppliers will look for more sources of fish species enabling to high production of fish skin collagens for the cosmetic uses from consumer point of view. This has created a behavioural economic backbone to support the need of Industry 4.0, in which social factor is of paramount importance for coastal management [8].

Based on a Hungary case study, Nagy et al. (2018) reported that application of more efficient production processes can achieve a higher productivity in terms of increased economic sustainability. 
Using the online questionnaire, the proportions of food industry (18.6\%) was considered high. The word 'food industry' is therefore in the list of Internet of Things.

In conclusion, the security of seafood in quality and quantity is expected to be of high public concern in line with Industry 4.0 especially in Goal \#9 and Goal \#12 under UNSDGs. There are definite no doubt the natural seafood resources from the fragile coastal environment will determine the life quality of the human population. To sustain the well-being of the public, the sustainability of our coastal environment is not only our responsibility but also our mission to educate our next generations on how to sustain our coastal environment.

\section{Acknowledgment}

None.

\section{Conflict of Interest}

No conflict of interest.

\section{References}

1. Maresova P, Soukal I, Svobodova L, Hedvicakova M, Javanmardi E, et al. (2018) Consequences of Industry 4.0 in Business and Economics. Economies 6: 46.
2. (2018) MITI (Ministry of International Trade and Industry) Industry 4WRD: NATIONAL POLICY ON INDUSTRY 4.0. ISBN 978-967-13593-6-5.

3. (2017) Industrial Internet Consortium. A Global Industry First: Industrial Internet Consortium and Plattform Industrie 4.0 to Host Joint IIoT Security Demonstration at Hannover Messe 2017.

4. Nagy J, Oláh J, Erdei E, Máté D, Popp J (2018) The Role and Impact of Industry 4.0 and the Internet of Things on the Business Strategy of the Value Chain-The Case of Hungary. Sustainability 10: 3491.

5. Yap CK Mussel Watch in Malaysia: Past. Present and Future. Universiti Putra Malaysia Press. Serdang. 137 page. ISBN 978-967-344-264-5, Malaysia.

6. Yap CK, Cheng WH, Karami A, Ismail A (2016) Health risk assessments of heavy metal exposure via consumption of marine mussels collected from anthropogenic sites. Sci Total Environ 553: 285-296.

7. Alves AL, Marques ALP, Martins E, Silva TH, Reis RL (2017) Cosmetic Potential of Marine Fish Skin Collagen. Cosmetics 4: 39.

8. Yap CK, Leow CS (2019) Social factors for coastal management: A short review and some insights. Global Journal of Civil and Environmental Engineering 1(1): 01-07. 